\title{
RESEARCH ON DETERMINING PERCEPTIONS AND ATTITUDES TOWARDS EMOJI USE IN DIGITAL MARKETING CAMPAIGNS*
}

\section{Oya ERU ${ }^{1}$}

Volkan YAKIN $^{2}$

\begin{abstract}
The effect of the digital revolution is spreading through all aspects of life. One of the newest periods of marketing strategy is digital marketing. The most intensive group using digital devices is young students. In addition, young consumers are the group that uses social media the most. Users who want to interact with younger generations use digital marketing technologies. Companies can use many tools for their digital marketing campaigns. The newest digital marketing tool can be considered emojis. The aim of this study is to investigate the attitudes and perceived benefits of young consumers towards emojis in emotional and rational advertising messages used in social media advertising campaigns. In order to realize the aim of the research, a questionnaire study was conducted on the students of the School of Applied Sciences. The research on 580 students revealed that emojis were more effective than traditional methods when they were used at the right time and on the target audience.
\end{abstract}

Keywords: Digital Marketing, Emoji, Social Media

\section{DİJITAL PAZARLAMA KAMPANYALARINDA EMOJİ KULLANIMINA KARŞI DÜŞÜNCE ve TUTUMLARIN BELİRLENMESİ ÜZERINNE BİR ARAŞTIRMA}

\section{ÖZ}

Dijital devrimin etkisi yaşamın neredeyse tüm yönlerine yayılmaktadır. Pazarlama stratejilerinin en yeni dönemlerinden biri ise dijital pazarlamadır. Dijital cihazları kullanan en yoğun grup genç tüketicilerdir. Ayrıca, genç tüketiciler de sosyal medyayı en yoğun kullanan gruptur. Genç tüketicilerle etkileşimli bir ilişki kurmak isteyen şirketler dijital pazarlama stratejilerini kullanmaktadırlar. Şirketler dijital pazarlama kampanyaları için birçok araç kullanabilir. En yeni dijital pazarlama aracı emojiler olarak kabul edilebilir. Bu çalışmanın amacı genç tüketicilerin sosyal medya reklam kampanyalarında kullanılan duygusal ve rasyonel reklam mesajlarındaki emojilere yönelik tutumlarını ve algılanan faydalarını araştırmaktır. Araştırmanın amacını gerçekleş̧irmek üzere Gerede Uygulamalı Bilimler yüksekokulu öğrencileri üzerinde deneysel yöntemle anket çalışması yapılmıştır. 580 öğrenci üzerinde gerçekleştirilen araştırma sonucunda, emojilerin doğru zamanda ve hedef kitle üzerinde kullanıldığında geleneksel yöntemlerden daha etkili olduğu görülmüştür.

Anahtar Kelimeler: Dijital Pazarlama, Emoji, Sosyal Medya

\footnotetext{
${ }^{1}$ Dr. Öğr. Üyesi, Bolu Abant İzzet Baysal Üniversitesi, oya.eru@ gmail.com, ORCID:0000-0002-6678-0156 ${ }^{2}$ Dr. Öğr. Üyesi, Bolu Abant İzzet Baysal Üniversitesi, volkanyakin@ gmail.com, ORCID: 0000-0001-65188348

*This is an extended version of the paper presented at the MMRA Marketing Congress 1-4 May 2019. Received/Geliş:01/06/2019 Accepted/Kabul: 31/07/2019, Research Article/Araştırma Makalesi Cite as/Alıntı: Eru, O. ve Yakın, V. (2019), "Research on Determining Perceptions and Attitudes towards Emoji Use in Digital Marketing Campaigns", Çukurova Üniversitesi Sosyal Bilimler Enstitüsü Dergisi, cilt 28, sayı 2, s.83-100.
} 


\section{Introduction}

The use of the internet via smartphones has given people easier access to the internet to search, purchase, or connect with what they want twenty-four-seven, 24 hours a day. However, these situations allow the influence of the digital revolution to spread into almost all aspects of life. According to the 2019 Global Report edited by Wearesocial, 4,388 billion of the total world's population are internet users. On the other hand, 5,112 billion of the total population of the world are unique mobile users and 3,484 billion active social media users (Kemp, 2019). According to GSMA Mobile Economy Report 2016, the number of smartphone connections globally will increase by 2.6 billion by 2020 . According to the report, the penetration rate of mobile users will reach $72 \%$ by 2020 globally. Thus, it can be said that the growing number of smartphones and other mobile devices increases the use of data intensive applications. With the increase in the usage of smartphones, companies who want to add digital marketing strategies to their marketing plans should act by taking into account this situation. However, mobile phones are not just used for communication. Also, mobile internet allows people to connect, search, reserve, or purchase what they want and whenever they want it. People use mobile devices because they do not want to cut connection with internet and social media.

Also with the use of the internet and social media, a new type of consumer arises. Thus, new consumers especially young ones, perform the following activities such as; search, like, dislike, follow, comment etc. New consumers adopt digital channels and platforms to their purchasing behaviors. They use smartphones as shopping assistants, and they review products or services online. New consumers have unlimited access to information about products or services. Therefore, it can be said that new consumers are more powerful compared to the traditional consumers. With the use of free tools available on the internet, consumers can compare prices and purchase conditions, verify suppliers, or even recommend products or services to their reference groups or followers. According to Ryan (2014), the development of the technology influences consumers. Consumers are being enabled to connect to each other more easily with digital technologies. Also, consumers can create their own contents and can share them with companies. With digital technologies, consumers can involve in the creation process of the products and services. According to the researches, it can be said that most of the consumers read online reviews before purchasing (Godes and Silva, 2012). Reducing time and effort, gaining access to more choices than available locally and finding the best price, helps to trigger consumer's involvement in online shopping too (Nielsen, 2016). So it is definitely clear that the most effective tool to reach these people is the internet. As such, a new marketing method is necessary. This new method could be identified as digital marketing. Digital marketing can be described as performing marketing activities via digital devices. Furthermore, the latest innovation in digital marketing can be described as emoji marketing.

Digital Marketing 
Digital marketing can be basically described as the promotion of products, services or brands via electronic media tools. According to Bird (2007), digital marketing could be described as marketing in which messages are sent using tools that depend on digital transmission.

Digital marketing differs from traditional marketing. This is because the channels and methods to reach consumers are different from that of traditional marketing. With digital marketing, companies can create a relationship with their consumers interactively. So it makes it possible to measure the feedbacks of their campaigns easier. And it can be said that with digital marketing, companies will take new opportunities and create new work areas. According to Leeflang et al. (2014), digital marketing is an important competitive advantage in $\mathrm{B} 2 \mathrm{~B}$ and $\mathrm{B} 2 \mathrm{C}$ marketing. With digital marketing, companies can be able to observe consumer's behaviors. According to Baines et al. (2013), reduction of management costs, execution speed, and user experience, is driving the marketers' interest in digital marketing activities. Rayport ve Sviokla (1995) expressed that, with digital marketing, scale economies are being developed and new formation of new business fields appeared. Consumers use multiple digital channels and these channels are cheaper than traditional marketing channels to reach consumers. Companies are able to collect data about their consumers with digital marketing. In addition, companies who hope to gain increasing sales, induce innovation, create brand loyalty, and enhance costumer's engagement from analyzing this data (Leeflang et al., 2014). Digital marketing increases sales because companies could reach a larger consumer size (Acar and Kayahan, 2007). Digital marketing provides added value to companies and consumers; provides interactive communication between consumers and companies; and provides companies with online brand extension. In addition, digital marketing provides small and medium enterprises with the opportunity to expand their market (Özel, 2012). Small businesses can offer unique products or services which can also be a very successful and profitable concept, especially if marketed well in digital platforms (Toksoy, 2010). With digital marketing, companies can create innovative campaigns.

E-mails, webcasting, mobile internet, QR codes, Bluetooth, mobile apps, contents, local based marketing tools, kiosks, the home page of companies' web sites, paid search words, paid banner ads, e-bulletins, search engine marketing, forums, and blogs and SMS and social media are the most common channels for digital marketing (Toksoy, 2010; Chaffey et al., 2012; Leeflang et al., 2014). One of these tools, "social media" has a massive role to play in digital marketing.

\section{Social Media}

Social media can be described as a platform that people can share, comment, create or exchange information with each other interactively. Today, there are many kinds of social media platforms that people can use in communicating with each other. Therefore, the most popular and frequently used of them include Facebook, Twitter, Youtube, Instagram, LinkedIn, Pinterest, Periscope, Snapchat, Foursquare, and Swarm. The intent 
usage of social media all over the world, triggers companies to reach their targeted clients through this channel. Social media has become a marketplace for companies and marketers. Social media allow companies to engage in timely and direct consumer contact at relatively low cost and at higher levels of efficiency than traditional marketing (Kaplan and Haenlein, 2010). According to DeMers (2014), using social media in marketing provides significant benefits to marketers. These benefits include: visibility, loyalty, diffusion, humanization, popularity, decreased costs, increased inbound traffic, and instant contact.

It is an effective strategy for companies to use social media for their advertising campaigns (Weinreich, 2007). Through social media, institutions achieve a variety of objectives such as one-to-one communication with the target consumer group, creating brand loyalty, transferring corporate messages, and achieving correct marketing decisions through returns from them (Köksal and Özdemir, 2013). According to Onat and Alikılı̨̧ (2008), the most important reasons for using social media in digital marketing campaigns such as digital advertising can be counted as; to reach more people with lower budgets, establishing an interactive communication with people, spreading campaigns to wider audiences, reaching the right target audience and measuring the success of the campaign. In addition, it is stated that people started to move away from traditional advertising media, in the studies. People who are constantly exposed to advertising messages through various channels during the day want to control their media consumption. so people want to access and view content that is appropriate to them (Faulds and Mangold, 2014; Tao, 2016). In this respect, social media is becoming an appropriate advertising tool for digital marketing activities. The most innovative and creative digital advertising campaigns carried out using social media are advertising campaigns with emojis.

\section{What Are Emojis?}

Although the popularity of today's visual communication is in line with the development of social media, the first use of non-verbal communication in digital media goes back to the 1990s. Pictograph, which includes emojis, was considered as an alternative to the standard language as well as the way to express emotions easily and automatically (Vidal et al., 2016). The first firm of the pictograph is called "emoticon." However, the term is usually used to refer to simple face visuals that are used for expressing emotions and moods in electronic messages (Whalter and D'Addario, 2001). Emojis are more elaborating versions of emoticons, and they were first used in Japan in 1999. Shigetaka Kurita, who is known as the father of emoji alphabets, developed the emojis to find a solution to the problem of character limits with text messages on mobile phones.

Emojis were meant to form a global language which is also based on the simple expression of feelings and thoughts (Golden, 2015). When compared to emoticons, emojis are more colorful, diverse, visual, and personal. Unlike the punctuations that are generally used by almost everyone, emojis allow users to express feelings to the receiver in a clearer and a more personal way (Shanghani, 2014). Researches conducted in 
different disciplines about the usage of emojis conclude that emojis have more benefits than what was initially thought. For instance, Churches et al. (2014) showed that people react to emojis the same way as they respond to real human faces. When negative feedback to receivers is provided along with positive emojis, that strengthens the receivers' perception of good intention communicated to them through the pretty equivalent feedback. Through this way, emojis help receivers tone, down their criticisms and, in return, receive the message more gracefully. By this way, emojis softens the blow of a critique (Wang et al., 2014). According to other findings in literature, people that uses emojis are more popular than their friends who do not, and they appear more friendly and competent; hence, emojis make a positive effect while increasing credibility when used in corporate e-mails (Tchokni et al., 2014; Kalyanaraman et al., 2013; Gacey et al., 2013).

Also, it was observed that emojis provide a more enjoyable and positive experience of communication, allow more personal interaction, and are perceived to be more useful than their alternatives (Huang et al., 2008). According to Emogi Report (2015), emojis are used by $92 \%$ of the online population. Most intense users of social media and emojis are the millennial generation; nearly $80 \%$ of millennials (age $<29$ years) use emojis.

Emojis help people to create personal relationships. Apart from helping people to be understood, they are easy to use and they are one of the means of communication. Today, communications are so rapid and emojis are the main fundamentals of this rapid digital communications. According to the Brenner (2015), millennials are addicted to social media. In addition, they are connected to the digital world and they mostly communicate increasingly with emojis.

Nowadays, there is abundance of information and this makes it more important to get attention from consumers. Consumers do not watch, read, or listen to a lot of long ad messages. As a result, this makes emojis to be used by companies to create a short, real, and emotional relation.

According to results of a study (www.fikrimuhim.com, 2018), that investigate users of emoji, $77 \%$ of participants who joined the research (7252 participant) stated that they use emojis in nearly all of their communications. According to the results, emojis are used mostly in mobile chat apps, Social media and mobile SMS. Also, emojis are mostly used on Facebook and Instagram. Communication with the use of emojis mostly takes place between friends (69\%). Participants, who use emojis in their communication preferences, use emojis to express their feelings better, support their ideas, and state many things within a short time period. Also, users of emojis believe that the use of emoji makes it easier to express ideas and avoid misunderstanding. According to research findings, two out of five people believed that emojis will replace words. According to Vidal et al. (2016), the results of the research considered 12,260 tweets about breakfast, lunch, dinner and snack eating situations where consumers express a wide range of positive and negative emotions. Thus, these emoticon and emoji use is tailored to the content of the tweets. According to Zhang et al. (2016), emojis can react like a real human face. Emojis are correlated with real-life happiness. According to Pavalanathan and Eisenstein (2015), 
emojis have been introduced to social media, and are increasingly popular. According to the findings of their study, emoticons were primarily designed using facial expressions to express emotion. However, they were also used to "establish more of a conversational connection, a playful interaction, or a shared and secret uniqueness within a particular relationship. Today, the purpose of emojis goes beyond facilitating interpersonal communications. The growing frequency of emoji usage in digital communications made companies realize the added value of visual expressions in written format. As such, these companies have started to use increasingly emojis more and more in their digital marketing communications campaigns for the past few years.

\section{Emoji Marketing}

Emoji marketing can be described as using emojis in digital marketing strategies and campaigns. There are a number of elements to be considered in order to use emoji in digital marketing campaigns. Among the most important are brands which are aimed at reaching the target audience.

Mostly, the target audience or potential audience are using emojis or going to use emojis in their communication. Thus, with digital marketing campaigns, companies will engage with target audiences. According to Tao (2016), in 2015 alone, tens of billions of messages with emojis were sent to over a billion users using Appboy technology. Yearover-year, the growth of campaigns using emojis has been $777 \%$. The month-over-month growth of emoji use in 2016 has been over $20 \%$ and is still increasing. According to Ross (2016), brands' usage of emojis is increasing.

Nowadays, brands recognize the power of emojis for their digital marketing campaigns. Brands use emojis to communicate with their target audience via audiences' mobile phones. Thus, they use emojis to express that they are using the latest communication trend, and they deliver their messages in a simple way. According to Lacy (2015), brands start to use emojis because more consumers start to use emojis. Tao (2016), stated that consumers are exposed to so many advertisements every day. So in this overloaded information environment, brands are struggling to stay relevant and communicate their message in few seconds to get the attention of consumers. Ge and Gretzel (2018), on the other hand, concluded that the use of emoji by social media phenomena is strategic and persuasive and also serves various communicative purposes. According to the Emoji Report (2015), consumers respond to ads with emojis; and emoji used real-time marketing campaigns to help to increase the click rates and Dwell time. The report expressed that the use of emojis in digital advertising represents the consumers' responses. Most of the consumers use very positive emojis when recommended something. Thus, if they found the digital ads to be familiar, they use neutral responses; and when they are interested in the digital ads, they use positive emojis again. Basically, two reasons affect consumers' positive emoji usage. When the ad is different from others, it stirs consumer's emoticons and they like to give an opinion; thus, emotional reasons trigger the use of positive emojis. On the other hand, if the ad is relevant, informative, important, clear, understandable, and interesting to the consumer, and if the consumer believes on the ad's message, cognitive reasons trigger consumers to use positive emoji. 
When composing advertising messages, they can be prepared with emotional content or rational content depending on their feelings or logic. Emotional advertising messages consist of fun, warm, friendly content, while rational content consists of logical content such as product/price information and brand name (Pelsmacker et al., 2002). From this point of view, the hypotheses and the research model (Figure 1) of the study were prepared as follows.;

H1a: There is a significant difference between the participants' attitudes towards emojicontaining emotional message and emoji-free emotional message.

H1b: Participants' perceptions of emoji-containing emotional message and emoji-free emotional message is significantly different.

H1c: Participants' attitudes towards rational advertising message with emoji and rational advertising message without emoji differ significantly.

H1d: Participants' perceptions about the benefit of rational advertising message with emoji and rational advertising message without emoji differ significantly.

Also, according to the literature it is seen that female participants use emogies more (Hwang 2014, Toksöz and Kahraman 2017). Thus, the second hyphothesis of the study can be seen below;

H2: Emoji usage status of participants varies according to gender.
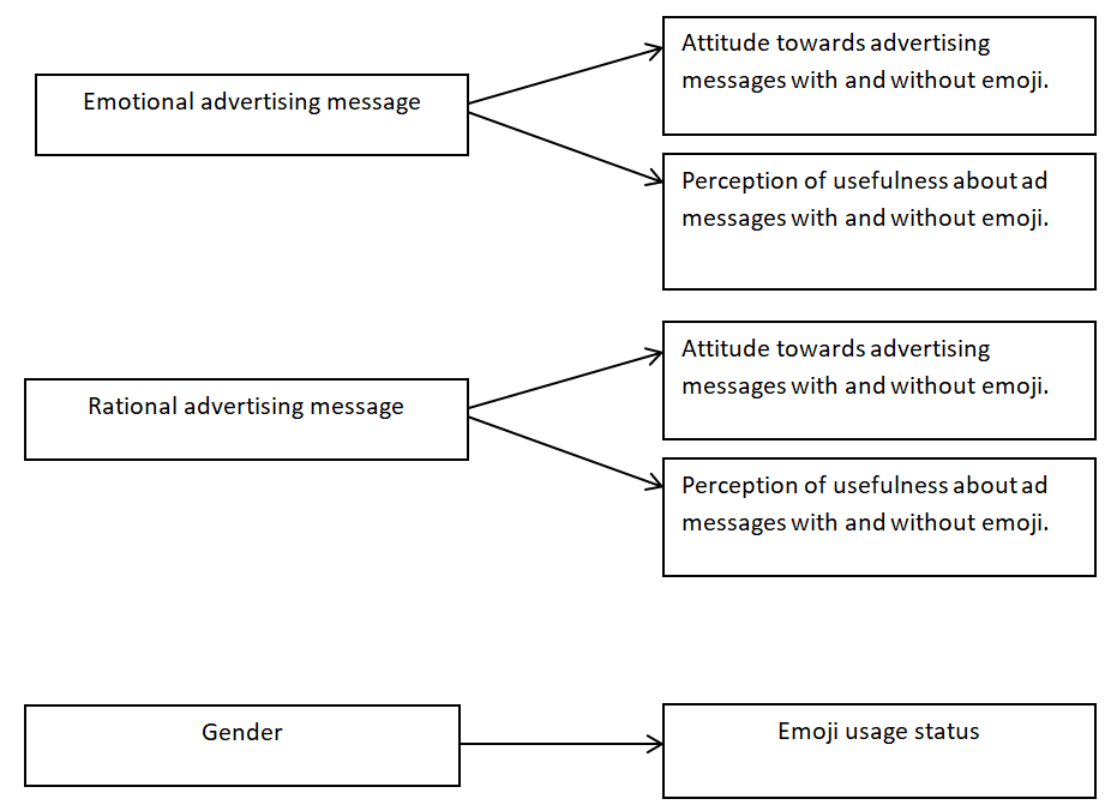

Figure 1. The Research Model

\section{Methodology}


The study was designed as an applied study. For the application part of the study, questionnaire technique was used. One of the scales used in the research was the emoji usage scale, Gökaliler and Saatçioğlu's (2016); scales related to advertising message,) Sheinin et al. (2011) and Haws et al. (2010). The questionnaire consists of 17 questions and three sections. The population of the study consists of social media users between the ages of 18-25. The reason why this age range is selected as the main population is that those who use social media and emojis most are in this age range (Emogi Research Team, 2016; Kemp, 2019; Brenner, 2015; fikrimuhim.com, 2015). Gerede School of Applied Sciences students were selected as samples. The school has 953 students. If the population is up to 1000 people with $95 \%$ confidence interval and sampling error $=0.05$, the sample size can be considered as 278 people (Yazıcıoğlu and Erdoğan, 2004). In the research, 580 students were reached. SPSS package program was used in the analysis of the collected data. Four advertising posters are designed for the application. Participants were asked to answer the questions in the questionnaire after reviewing the poster shown to them. The advertising posters used in the research were prepared in relation to goods and services. The first of the posters (figure 2) was prepared using emojis, consisting of an emotional advertising message 144 participant. The second poster (figure 3 ) contains an emotional advertising message but does not contain emojis 143 participant. The third poster (figure 4) was prepared with rational advertising message content and with emojis 151. The fourth poster (figure 5) was prepared without the use of emojis and contains rational advertising message 142 . The posters were shown to four different groups and we determined that the participants' attitudes towards advertising messages and their perceptions about the benefit of the advertising message.

CARINTA iyi hissettirir.

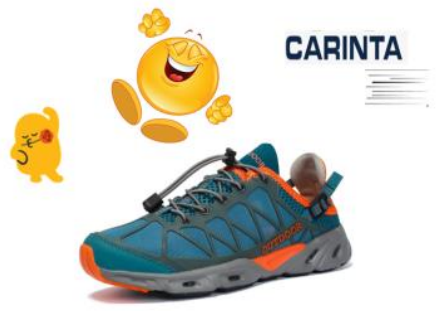

Figure 2
CARINTA iyi hissettirir

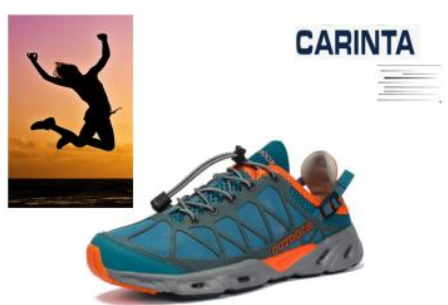

Figure 3

Artık ayaklarınıza kara sular inmeyecek!

Artık ayaklarınıza kara sular inmeyecek!
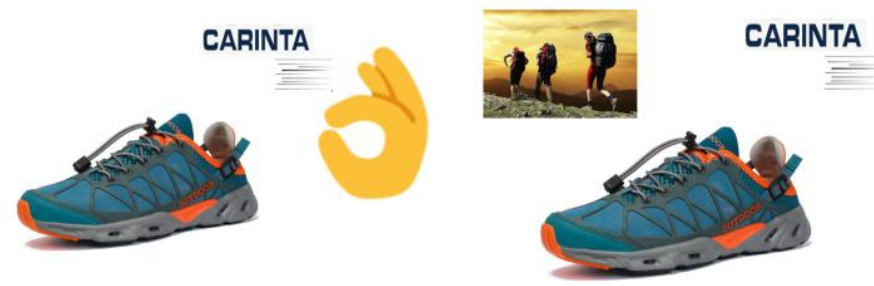
Ç.Ü. Sosyal Bilimler Enstitüsü Dergisi, Cilt 28, Sayı 2, 2019 Sayfa 83-100

Figure 4

Figure 5

\begin{tabular}{|l|l|l|l|l|l|l|l|l|l|}
\hline \multirow{2}{*}{ Gender } & \multirow{2}{*}{$\%$} & \multicolumn{2}{|l|}{ 1.Group } & \multicolumn{2}{l|}{ 2.Group } & \multicolumn{2}{l|}{ 3.Group } & 4.Group \\
\cline { 3 - 10 } & & $\mathrm{F}$ & $\%$ & $\mathrm{~F}$ & $\%$ & $\mathrm{~F}$ & $\%$ & $\mathrm{~F}$ & $\%$ \\
\hline Women & 49,3 & 65 & 46 & 82 & 57 & 61 & 40 & 80 & 56 \\
\hline Men & 50,7 & 79 & 54 & 61 & 43 & 92 & 60 & 62 & 44 \\
\hline Total & 144 & 100 & 143 & 100 & 153 & 100 & 142 & 100 \\
\hline
\end{tabular}

\section{Findings}

When the findings of the study were examined, it was concluded that $49.3 \%$ of the participants were women and 50.7\% were men (Table1). According to the findings, female participants stated that they used emoji when they were messaging more than male participants. Also, female participants stated that emoji was a way of expressing emotions, that it was fun to use emoji, and that they could better understand the feelings of the other party when an emoji message came, more than male ones. From this point of view, it can be stated that the findings obtained in the research have reached similar results as those in the literature. In the literature, it is stated that using emoji is the easiest way to express emotions, emojis messages are more effective and more fun (Huang et al., 2008; Vidal et al., 2016; Shanghani, 2014; Wang et al., 2014; Churches et al.., 2014; fikrimuhim.com, 2015; Özdemir et al., 2019; Hsieh and Tseng, 2015; Gökaliler and Saatçioğlu; Toksöz and Kahraman, 2017).

Table1. Distribution of Participants by Gender

The developed Hypotheses in order to determine the attitudes and perceived benefits of the participants to the messages of social media advertising campaigns with emotional content and rational content, with and without emojis, are tested with Mann Witney $U$ tests. before hypothesis testing, Factor analysis has been conducted. Explanatory factor analysis was applied to determine the factor structure of the expressions in the scale. KMO and Barlett sphericity test were used to perform factor analysis.

Table 2. Results of KMO and Bartlett's Test

\begin{tabular}{|l|l|r|}
\hline \multicolumn{3}{|c|}{ KMO and Bartlett's Test } \\
\hline Kaiser-Meyer-Olkin Measure of Sampling Adequacy. &, 895 \\
\hline Bartlett's Test of Sphericity & Approx. Chi-Square & 5420,999 \\
\cline { 2 - 3 } & Df &, 000 \\
\cline { 2 - 3 } & Sig. & \\
\hline
\end{tabular}


Test results show that the expressions are suitable for factor analysis, (KMO value, 0.895 and chi-square value, 5420,999, $\mathrm{p}<0,000)$. After, KMO and Bartlett's Tests, factor analysis has been conducted. When factor loadings were taken into consideration, 2 factor items below 0,300 and loading more than one factor were excluded from the scale. These substances are 4.-8. scale items consisting of questions. As a result of factor analysis, 3 factors (perceived benefit of advertising message, attitude towards advertising message, and emoji use status) measure $72,232 \%$ of explained variance. Reliability analysis (reliability coefficient for factor $1,0.874$, reliability coefficient for factor 2, 0.875 and factor 3 for factor $3,0.891$ ) were applied for the reliability of the scales. The results of the factor analysis can be seen in Table 3;

Table 3. Results of Factor Analysis

\begin{tabular}{|c|c|c|c|}
\hline Components & & $\begin{array}{l}\% \text { of Total Variance } \\
\text { Explained }\end{array}$ & Cronbach'sAlpha \\
\hline Component 1 /Ad. Usefulness & $\begin{array}{l}\text { Factor } \\
\text { Loadings }\end{array}$ & 42,245 & 0,875 \\
\hline 1. This ad. is believable. & 0,627 & & \\
\hline 2. This ad provides relevant information. & 0,931 & & \\
\hline $\begin{array}{l}\text { 3. This ad does a good job of presenting the } \\
\text { product's benefits. }\end{array}$ & 0,775 & & \\
\hline 4. This ad provides practical information. & 0,568 & & \\
\hline Component 2/ Ad. Attitude & & 65,307 & 0,874 \\
\hline 5.I enjoyed the ad. & 0,892 & & \\
\hline 6. I liked the ad. & 0,804 & & \\
\hline 7. This ad is a catchy ad & 0,785 & & \\
\hline 8. This ad is a catchy ad & 0,811 & & \\
\hline 9. This ad excited me. & 0,847 & & \\
\hline Component 3 /Emoji Usage & & 72,232 & 0,891 \\
\hline $\begin{array}{l}\text { 10. I use emoji when messaging with my } \\
\text { friends on my social media accounts }\end{array}$ & 0,833 & & \\
\hline $\begin{array}{l}\text { 11. I think using emoji is a way to express } \\
\text { our feelings today }\end{array}$ & 0,857 & & \\
\hline
\end{tabular}


Ç.Ü. Sosyal Bilimler Enstitüsü Dergisi, Cilt 28, Sayı 2, 2019 Sayfa 83-100

\begin{tabular}{|c|c|}
\hline 12. Using emoji is fun & 0,898 \\
\hline $\begin{array}{l}\text { 13. I think emojis provide information } \\
\text { about the personality of the emojis senders }\end{array}$ & 0,719 \\
\hline $\begin{array}{l}\text { 14. When I receive an emoji message while } \\
\text { messaging, I can better understand the } \\
\text { feelings of the person I'm texting. }\end{array}$ & 0,856 \\
\hline
\end{tabular}

As a result of factor analysis, three factors were obtained. These are; Ad.

Usefulness, Ad. Attitude and Emoji Usage.

Since the data obtained were not normally distributed, hypotheses were tested using nonparametric tests. For this purpose, Man Whitney U Test was applied (Table 4).

Table 4. Results of The Mann Whitney U tests For Hyphothesis

\begin{tabular}{|c|c|c|c|c|c|c|}
\hline Hyphothesis & $\mathrm{N}$ & Mean rank & Wilcoxon W & $\mathrm{U}$ & $\mathrm{P}$ & \\
\hline \multirow[t]{2}{*}{ H1a } & 144 & 159,33 & 22943,00 & \multirow[t]{2}{*}{8089,000} & \multirow[t]{2}{*}{,002 } & \multirow[t]{2}{*}{ Accepted } \\
\hline & 143 & 128,57 & 18385,00 & & & \\
\hline \multirow[t]{2}{*}{ H1b } & 144 & 146,02 & 21027,00 & \multirow[t]{2}{*}{10005,000} & \multirow[t]{2}{*}{,678 } & \multirow[t]{2}{*}{ Rejected } \\
\hline & 143 & 141,97 & 21301,00 & & & \\
\hline \multirow[t]{2}{*}{ H1c } & 153 & 153,95 & 23554,50 & \multirow[t]{2}{*}{9952,500} & \multirow[t]{2}{*}{,212 } & \multirow[t]{2}{*}{ Rejected } \\
\hline & 142 & 141,59 & 20105,50 & & & \\
\hline \multirow[t]{2}{*}{ H1d } & 153 & 150,66 & 23051,00 & \multirow[t]{2}{*}{10456,000} & \multirow[t]{2}{*}{,577 } & \multirow[t]{2}{*}{ Rejected } \\
\hline & 142 & 145,13 & 20609,00 & & & \\
\hline \multirow[t]{2}{*}{$\mathrm{H} 2$} & 287 & 321,05 & 91819,00 & \multirow[t]{2}{*}{33306,000} & \multirow[t]{2}{*}{,000 } & \multirow[t]{2}{*}{ Accepted } \\
\hline & 295 & 260,79 & 76671,00 & & & \\
\hline
\end{tabular}

When the hypothesis test results are evaluated; When the attitudes of the participants towards the emotional message containing the emoji and the emotional message without the emoji were compared, a significant difference was found between the emotional message containing the emoji and the emotional message without the emoji (H1a: Accepted).

There was no significant difference between the perceptions of the participants about the benefit of the emotional message containing the emoji and the benefit of the emotional message without the emoji (H1b: Rejected).

There is no significant difference between participants' attitudes towards rational advertising message containing emoji and rational advertising message without emoji (H1c: Rejected). 
There was no significant difference between the participants' perceptions of the rational advertising message containing emoji and the benefit of rational advertising message without emoji (H1d: Rejected).

Emoji usage of the participants varies according to their gender. Female participants use emojis more than male users (H2: Accepted).

\section{Conclusion and Recommendations}

Today, there is a very important competition between brands. In this competition, the brands which will retain their brand power will be differentiated from the others. In addition, consumers are continuously exposed to ads and they get bored with it. After all, with the rise of mobile internet, usage of smartphones, and the rise of the intense interest for social media, new marketing strategies of companies is inevitable. From this point of view, it can be said that companies who want to reach consumers, and who want to relate an interactive loyalty, have to create new, friendly, innovative, and smart campaigns. In addition, the newest trend in digital marketing involves the use of emoji in marketing campaigns.

From this point of view, the aim of this study is to investigate the attitudes and perceived utility of young people towards emojis used in social media advertising campaigns. Although the use of emojis in digital marketing has been increasing day by day, limited research has been found in the marketing literature related to determining perceptions and attitudes towards the benefit of advertising when social media ads are used. This situation was the most decisive factor in conducting the research. Another dimension that distinguishes this research from other studies is that it compares advertising messages emotionally and rationally.

Researches conducted in other disciplines related to emojis states that people perceive emojis as real human emotions, that emojis are the simplest and fastest way to express emotions, and that using emoji is fun (Golden, 2015; Churches et al., 2014; Huang et al., Huang, et al. 2008; Vidal et al., 2016; Shanghani, 2014; Wang et al., 2014; fikrimuhim.com, 2015; Özdemir et al., 2019; Hsieh and Tseng, 2015; Gökaliler and Saatçioğlu; Toksöz and Kahraman, 2017). The results of the study are in parallel with the results obtained in the literature.

The participants stated that using emoji is a way of expressing emotions, that using emoji is fun and that they can better understand the feelings of the other person when they receive an emoji message while messaging. There is a significant difference between the attitudes of the participants towards the advertising messages using emotional content emoji and the attitudes towards the emotional advertising message without emojis. Novak et al. (2015) stated that emoji messages were more effective on people than non-emoji messages, so it would be beneficial for enterprises to add emoji to their campaign messages in their digital marketing campaigns. Again, according to the Emoji Report prepared in 2015, it is stated that consumers react more to emoji content advertising messages and that emojis will increase the clickthrough rate of businesses in the real-time digital advertising campaigns. 
The attitudes of the participants towards the rational advertising message do not differ whether or not emoji is used in the advertising message. Therefore, as it is stated in the literature, it can be said that emojis will be a more suitable promotion tool for advertising messages with emotional content due to their structure reflecting emotions. It is stated in the literature that as the creativity of advertising campaign increases, the attitude towards advertising is positive (Gökaliler and Saatçioğlu, 2016). When the results of the research are evaluated, it is seen that female participants use emogies more. This result is similar to previous results in the literature (Hwang 2014, Toksöz and Kahraman 2017). From this point of view, it can be said that the inclusion of emojis in the advertising messages of the enterprises that want to reach their female customers via social media will create a positive attitude for female customers.

Companies want their marketing processes to be successful with low costs but more effectiveness. To create this, they can benefit from the advantages of emojis. Companies began to use social media platforms intensively in their advertising campaigns. And emojis are also an important element of social media. Therefore, it is believed that the results obtained by this study will guide the enterprises.

The fact that emojis are associated with emotions, perceived as a common language and leave a positive effect can lead businesses to create advertising messages with emoji content. In this way, businesses can find a more interactive and positive relationship with their users.

Since using emojis in social media advertising messages will be more engaging and creative than traditional advertising messages, emojis can also give users a positive attitude towards emotional advertising messages. Tao (2016) stated that as long as people use social media, emojis will be a creative tool for marketers and businesses. So, it can be expressed that continuing developments and improvements in emoji marketing will take attention of such companies to employ emoji oriented marketing strategies in their future works. According to Köse and Sert (2015), social media environments are used by many companies to improve effectiveness and efficiency. Thus, it can be said that if companies deliver the right message at the right time to the consumers, social media will be a highly efficient medium for marketing. Today's millennials are future's consumers. Therefore, to reach them in the future with emoji marketing, companies have to take into account some points; companies have to use emojis at the right time with the right content; companies have to create a story in their content and not to use emojis in all of their contents; companies have to use emojis if they want to create an engaging experience with their consumers; and companies have to use emojis if they think that emojis are relevant and beneficial for their digital campaign. In addition, companies have to remember that emojis can be used as one tool in digital campaigns. They have to be used together with other tools, such as games, hashtags, etc. Not every brand needs to integrate emoji's into their campaigns, but they have to keep an eye on their consumers' passion points. It should be noted that the most important feature of emoji is the same meaning in all languages. As a result, companies can benefit from this feature. it can be said that, when generating digital marketing campaigns, the use of emojis will be very successful when used at the right time and for the right consumers. 
If the target audience were members of babyboomers or $\mathrm{x}$ generation, using emojis cannot bring positive results. Also, it has been considered that emojis reflect emotions. So, in order to create successful campaigns, brands have to use emojis that appeal to the emotions of consumers. Also, brands have to analyze consumers' usage aims of emojis to trigger them to relate with the brand and to attract the attention of consumers. Novak et al. (2015) expressed that tweets with emojis are more emotionally loaded and have a significant impact on the perception of the human emotion. According to the results of the study, it can be said that emojis are mostly use at the end of the tweets. As a result, it can be suggested to the brands who want to use emojis in digital marketing campaigns.

Emojis will be a new digital marketing tool to reach consumers. Emojis become a powerful form of promotion because they empower self-expression and allow brands to enter $\mathrm{C} 2 \mathrm{C}$ conversations in an organic way. With emojis, brands can be able to add an emotional layer to their marketing strategies. Also, emojis are widespread, easily recognized, and it transcends the language and cultural barriers. However, these situations trigger brands to use emojis in their digital marketing strategies. While there are opportunities for brands that use emojis, there is also some danger too. First of all, emojis may not fit for every brand. Also, brands should not just try to use emoji for testing or to have fun, but they have to analyze if their audiences adopted emojis. According to Brenner (2015), if brands want to start using emojis in their digital campaigns, they have to consider some factors. If brands want to do emoji marketing, they have to use the latest technology and think mobile first. Brands also should think about what their consumers care about or think. This makes brands more humanistic. According to Shayon (2015), when a brand shows up in the right way and at the right place, it can make that relationship even stronger.

The findings of the study are limited to the answers given by the participants. The fact that the research was conducted only on GUBYO students limited the comparison of different generations. Time and cost constraints are other constraints in terms of conducting research on a wider audience. Further research can be carried out with wider samples and different perspectives such as the effect of emojis on purchasing intention and the brand awareness, in addition to identifying thoughts and attitudes towards advertising messages by including different age groups in the research.

\section{References}

Acar, E. ve Kayahan C. (2007). Elektronik Ticaret ve Elektronik İş. İstanbul: Nobel Yayın Dağıtım.

Baines, P., Fill, C., \& Page, K. (2013). Essentials of Marketing. Oxford University Press. Bird, D. (2007). Commonsense Direct and Digital Marketing. Kogan Page Publishers.

Brenner, M. (2015). The rise of the emoji for brand marketing. Retrieved from: http://www.theguardian.com/media-network/2015/jan/26/rise-emoji-brandmarketing (20.05.2019)

Chaffey, D., Smith, P. R., \& Smith, P. R. (2012). eMarketing eXcellence: Planning and Optimizing Your Digital Marketing. Routledge.

Churches, O., Nicholls, M., Thiessen, M., Kohler, M., Keage, H. (2014). Emoticons in Mind: An Event-related Potential Study. Social Neuroscience, 9(2), 196-202 
Ç.Ü. Sosyal Bilimler Enstitüsü Dergisi, Cilt 28, Sayı 2, 2019 Sayfa 83-100

DeMers, J. (2014). The Top 10 Benefits of Social Media Marketing. Retrieved from: http://www.forbes.com/sites/jaysondemers/2014/08/11/the-top-10-benefits-ofsocial-media-marketing/\#282b56c82a4d (08.10.2019)

Faulds, D. J., \& Mangold, W. G. (2014). Developing A Social Media and Marketing Course. Marketing Education Review, 24(2), 127-144.

Gacey J. H., Moore L., Gallo J., (2013). Some Science Behind the Smiley, Emoticons and Their Possible Impact on The Workplace. Retrieved from: http://www.hrfloridareview.org/item/266-some-science-behind-the-smileyemoticons-and-their-possible-impact-on-the-workplace (11.06.2019)

Ge, J., \& Gretzel, U. (2018). Emoji Rhetoric: A .Social Media Influencer Perspective. Journal of Marketing Management, 34(15-16), 1272-1295.

Global Connected Commerce Is e-tall Therapy The New Retall Therapy? Retrieved from:http://www.nielsen.com/content/dam/nielsenglobal/jp/docs/report/2016/Nie lsen-Global-Connected-Commerce-Report-January-2016 (27.06.2019)

Godes, D., \& Silva, J. C. (2012). Sequential and Temporal Dynamics of Online Opinion. Marketing Science, 31(3), 448-473.

Golden L. (2015). Emoji History: The Background, History, and Future of The Symbols That Have Taken Over Conversation All Over The World. Retrieved from: https://storify.com/lindsaygolden/emojis-history (17.08.2019)

Gökaliler, E., \& Saatçioğlu, E. (2016). Bir Reklam Unsuru Olarak Emoji Kullanımı: Emoji İçerikli Reklamlara Yönelik Tutum Araştırması. Selçuk Üniversitesi Sosyal Bilimler Meslek Yüksek Okulu Dergisi, 19(2), 63-91.

GSMA Mobile Economy Report 2016 Retrieved from: https://www.gsma.com/mobileeconomy/2016/global/

Haws, K. L., Dholakia, U. M., \& Bearden, W. O. (2010). An assessment of chronic regulatory focus measures. Journal of Marketing Research, 47(5), 967-982.

Huang, A. H., Yen, D. C., \& Zhang, X. (2008). Exploring the Potential Effects of Emoticons. Information \& Management, 45(7), 466-473.

Hsieh SH \& Tseng TH, (2015). The Effects of Emoticons and Text-Messaging on Social Interaction: Playfulness in Mobile Instant Messaging. In PACIS: 220.

Hwang, H. S. (2014). Gender Differences in Emoticon Use on Mobile Text Messaging: Evidence from a Korean Sample. International Journal of Journalism \& Mass Communication. Retrieved from http://dx.doi.org/10.15344/23492635/2014/107 (05.06.2019)

Kalyanaraman, S. and Ivory, J. D. (2006). The Face of Online Information Processing: Effects of Emoticons on Impression Formation, Affect, and Cognition in Chat Transcripts. Retrieved from: http://citation.allacademic.com/meta/p_mla apa research_citation/0/9/3/2/8/pag es93286/p93286-1.php (16.07.2019)

Kaplan, A. M., \& Haenlein, M. (2010). Users of the world, unite! The challenges and opportunities of Social Media. Business Horizons, 53(1), 59-68.

Kemp, S. (2019). Digital in 2019, Retrieved from: http://wearesocial.com/specialreports/digital-in-2019 (17.07.2019) 
Köksal, Y., and Özdemir, Ş. (2013). Bir İletişim Aracı Olarak Sosyal Medya'nın Tutundurma Karması İçerisindeki Yeri Üzerine Bir İnceleme. Süleyman Demirel Üniversitesi İktisadi ve İdari Bilimler Fakültesi Dergisi, 18(1).

Köse, U., \& Sert, S. (2015). Social Media Environments and Their Role On Success Of Marketing Processes. Bilgi Ekonomisi ve Yönetimi Dergisi, 10(2).

Lacy, L. (2015). Emoji Marketing: What Brands Need to Know. Retrieved from: http://www.momentology.com/5866-emoji-marketing/ (20.07.2019)

Leeflang, P. S., Verhoef, P. C., Dahlström, P., \& Freundt, T. (2014). Challenges and Solutions for Marketing in A Digital Era. European Management Journal, 32(1), $1-12$.

Novak, P. K., Smailović, J., Sluban, B., \& Mozetič, I. (2015). Sentiment of Emojis. Retrieved from: https://doi.org/10.1371/journal.pone.0144296

Onat, F., \& Alikılıç, Ö. A. (2008). Sosyal Ağ Sitelerinin Reklam ve Halkla İlişkiler Ortamları Olarak Değerlendirilmesi. Journal Of Yaşar University, 3(9), 11111143.

Özel, M. (2012). Öğrencilerin Sosyal Medya Kullanımını ve Üniversitelerde Dijital Pazarlama İletişimi Uygulamalarını Belirlemeye Yönelik Bir Araştırma. (Beykent Üniversitesi, Sosyal Bilimler Enstitüsü, Yükseklisans Tezi, İstanbul). Retrieved from: https://tez.yok.gov.tr/UlusalTezMerkezi

Pavalanathan, U., and Eisenstein, J. (2015). Emoticons vs. Emojis on Twitter: A Causal Inference Approach. Retrieved from: https://arxiv.org/abs/1510.08480 (19.07.2019)

Rayport, J. F., \& Sviokla, J. J. (1995). Exploiting the Virtual Value Chain. Harvard Business Review, 73(6), 75.

Pelsmacker, P.D., Maison, D., Geuens, M. (2002). Emotional and Rational Advertising Messages in Positive and Negative Polish Media Contexts Emotional. New Directions in International Advertising Research, 12: 114-128.

Ross, P. (2016). Emoji Marketing is Growing Fast. Retrieved from: http://www.socialbakers.com/blog/2510-emoji-marketing-isgrowing-fast (21.07.2019)

Ryan, D. (2014). Understanding Digital Marketing: Marketing Strategies for Engaging The Digital Generation. Kogan Page Publishers.

Shayon,S. (2015). Snaps Emoji Keyboards Give Brands a Visual Voice. Retrieved from: http://brandchannel.com/2015/04/16/snaps-emojis-041615/ (22.07.2019)

Sheinin, D. A., Varki, S., \& Ashley, C. (2011). The Differential Effect of Ad Novelty and Message Usefulness on Brand Judgments. Journal of Advertising, 40(3), $5-18$.

SwiftKey Emoji Report. (2015). Retrieved from: https://tr.scribd.com/doc/262594751/SwiftKey-Emoji-Report (27.07.2019)

Tao, J. (2016). Emojis Are Now Used in 777\% More Campaigns Than Last Year. Retrieved from: https://blog.appboy.com/emojis-used-in-777-morecampaigns/ (21.07.2019)

Tchokni S., Śeaghdha O D., Quercia D. (2014). Emoticons and Phrases: Status Symbols in Social Media. Retrieved

from: 
Ç.Ü. Sosyal Bilimler Enstitüsü Dergisi, Cilt 28, Sayı 2, 2019 Sayfa 83-100

http://www.aaai.org/ocs/index.php/ICWSM/ICWSM14/paper/view/8103 $(17.05 .2019)$

Toksoy, H.I. (2010). An Emerging Concept: Digital Strategies And I-Marketing, Master Thesis. İstanbul Technical University, Institute of Science and Technology, İstanbul. Retrieved from: https://tez.yok.gov.tr/

Toksöz, L., \& Kahraman, C. (2017). Türk Üniversite Öğrencilerinin Emoji Algısı. Humanitas, International Journal of Social Sciences, 5(9).

Shanghani, (2014). How 2014 Became The Year of The Emoji, Retrieved from: http://www.telegraph.co.uk/women/womenslife/11312346/E moji-why-wereall-so-obsessed.html (27.05.2019)

Türk İnsanı Hangi Emojileri Kullanıor? Retrieved from: http://www.fikrimuhim.com/Binary/Images/Upload/Report/DA_Emoji\%20Arast irmasi.pdf. (30.07.2019)

Vidal, L., Ares, G., \& Jaeger, S. R. (2016). Use of Emoticon and Emoji in Tweets for Food-related Emotional Expression. Food Quality and Preference, 49, 119-128

Wang, W., Zhao, Y., Qiu, L., \& Zhu, Y. (2014). Effects of Emoticons on the Acceptance of Negative Feedback in Computer-Mediated Communication. Journal of the Association for Information Systems, 15(8), 454.

Walther, J. B., \& D'Addario, K. P. (2001). The Impacts of Emoticons on Message Interpretation in Computer-Mediated Communication. Social science computer review, 19(3), 324-347.

Weinreich, N. K., (2007), What Is Social Marketing?, Usa: Weinreich Communications.

Yazıcıŏglu, Y., \& Erdoğan, S. (2004). SPSS Uygulamalı Bilimsel Araştırma Yöntemleri. Detay Yayınc1lı, Ankara.

Zhang, J., Han, S. W., \& Chang, J. (2016). Emerging Trends In Social Media. Retrieved from: http://www.ijctjournal.org/Volume3/Issue2/IJCT-V3I2P6.pdf (31.07.2019)

2015 Emoji Report. Retrieved from: $\begin{array}{ccc}\text { http://emogi.com/documents/Emoji Report 2015.pdf (07.07.2019) } & \text { Report. } & \text { Retrieved } \\ \text { Emoji } & \text { from: }\end{array}$

https://cdn.emogi.com/docs/reports/2016_emoji_report.pdf (08.072019) 